NURSING MODELS AND THE NURSING PROCESS 


\title{
Nursing Models and the Nursing Process
}

\author{
Peter Aggleton \\ Helen Chalmers
}




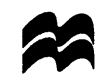

(C) Peter Aggleton and Helen Chalmers 1986

All rights reserved. No reproduction, copy or transmission of this publication may be made without written permission.

No paragraph of this publication may be reproduced, copied or transmitted save with written permission or in accordance with the provisions of the Copyright, Designs and Patents Act 1988, or under the terms of any licence permitting limited copying issued by the Copyright Licensing Agency, 90 Tottenham Court Road, London W1P 9HE.

Any person who does any unauthorised act in relation to this publication may be liable to criminal prosecution and civil claims for damages.

First published 1986 by

MACMILLAN PRESS LTD

Houndmills, Basingstoke, Hampshire RG21 6XS

and London

Companies and representatives

throughout the world

ISBN 978-0-333-41665-5

ISBN978-1-349-18450-7 (eBook)

DOI 10.1007/978-1-349-18450-7

A catalogue record for this book is available from the British Library.

This book is printed on paper suitable for recycling and made from fully managed and sustained forest sources.

$\begin{array}{llllllll}18 & 17 & 16 & 15 & 14 & 13 & 12 & 11\end{array}$

$\begin{array}{lllllllll}05 & 04 & 03 & 02 & 01 & 00 & 99 & 98 & 97\end{array}$

The reader should note that all references in this book to one gender should also be read as applying to the other gender unless specifically indicated otherwise. 


\section{Contents}

Preface vii

1 Introduction 1

2 The Medical Model of Care 11

3 Henderson's Model of Nursing 17

4 Roper, Logan and Tierney's Activities of Living Model of Nursing 27

5 Johnson's Behavioural Systems Model of Nursing 37

6 Roy's Adaptation Model of Nursing 47

7 Orem's Self-Care Model of Nursing 59

8 Riehl's Interactionist Model of Nursing 71

9 Rogers's Unitary Field Model of Nursing 85

10 From Nursing Models to Nursing Theory 99

References 111

Index 115 


\section{Preface}

If asked, perhaps the majority of nurses today would express an interest in improving standards of care. Among them a significant proportion would probably claim that the introduction of the nursing process has been an important step towards attaining such a goal. However, as many practising nurses are only too well aware, the nursing process by itself is an essentially empty approach to care. On its own, it exhorts nurses to assess, but tells them little about what to assess. It encourages planning, but says little about how to plan. It asks nurses to intervene, but fails to say in what ways. It advocates evaluation, but does not specify when or how.

In the light of this, the reserve that many nurse practitioners have felt about the nursing process seems justified. In many areas of their work nurses have been expected to introduce the nursing process without a set of guidelines about how to apply it. Alternatively, the nursing process has been used uncritically to organise nursing care around a set of medical understandings of people and their needs. Both of these situations are clearly unreasonable, since they seek to deny the work of practising nurses who, over the last twenty years, have tried to develop alternative ways of thinking about people and their health-related needs. To us the use of the nursing process in this way would seem to suggest either that there is nothing that nurses can learn from each other or that they should continue to act in ways which are essentially determined by medical priorities and interests.

In producing this book our aim is to introduce practising nurses to a number of models of nursing which can act as guidelines for the use of the nursing process. To many nurses the idea of a nursing model may seem a strange one. Essentially, though, models of nursing are little more than sets of ideas about people and nursing 
care which can be used as guides for the planning and delivery of nursing care.

Contrary to the claims of writers such as Miller (1985), in writing this book we, as nurse educators, do not seek to impose change on nursing practice. Neither do we accept the suggestion that nurse practitioners 'rarely question the knowledge which guides their action'. We firmly believe that the relationship between nursing theory and nursing practice can only be strengthened when nurse educators turn to nurse practitioners for a critical evaluation of the ideas they propose.

Thus, within this book we aim to describe rather than criticise a number of nursing models. Our emphasis on description is a deliberate one, because it must be for practising nurses to decide on the usefulness or otherwise of nursing models. However, in the final chapter of this book we provide some guidelines about how this evaluation might take place.

In producing this book we owe a debt to friends and colleagues in Bath and Bristol, and to the many nurses we have taught since our imaginations were first aroused by the possibility of an informed yet critical nursing practice.

Bristol and Bath, 1986

P.A.

H.C. 